\title{
MENCIPTAKAN SMART ASN MENUJU 4.0 DI KANTOR CAMAT KECAMATAN SITINJAU LAUT KABUPATEN KERINCI
}

\author{
PEBI JULIANTO \\ STIA NUSANTARA SAKTI SUNGAI PENUH \\ INSTITUT AGAMA ISLAM NEGERI KERINCI \\ Email : \\ pebijulianto@gmail.com
}

\begin{abstract}
This study aims to determine SMART ASN Towards 4.0 in the Apparatus of Sitinjau Laut District, Kerinci. This study uses a descriptive qualitative research method with in-depth interview approach using interview guidelines with the problem under study and documentation. From the results of data analysis, it can be concluded that to determine the quality of SMART ASN Towards 4.0 at the Sitinjau Laut District Office at this time, researchers used six dimensions of quality SMART ASN Towards 4.0, namely Recruitment of Prospective Civil Servants (CPNS) using Computer Assisted Test (CAT), Development career patterns, competency development, career development, promotion through open selection, and succession plans in creating SMART ASN Towards 4.0 at the Sitinjau Laut subdistrict office. Government tasks are carried out in the context of carrying out general government functions which include the empowerment of institutions, personnel, and administration. Meanwhile, certain development tasks are carried out through economic and social development aimed at increasing the welfare and prosperity of the entire community.
\end{abstract}

Keywords: SMART, ASN Towards 4.0.

\begin{abstract}
ABSTRAK
Penelitian ini bertujuan untuk mengetahui SMART ASN Menuju 4.0 di Kantor Camat Kecamatan Sitinjau Laut Kabupaten Kerinci. Penelitian ini menggunakan metode penelitian Kualitatif Deskriptif dengan Pendekatan wawancara mendalam dengan menggunakan pedoman wawancara dengan masalah yang diteliti dan Dokumentasi. Dari hasil analisis data, dapat disimpulkan bahwa untuk mengetahui kualitas SMART ASN Menuju 4.0 di Kantor Kecamatan Sitinjau Laut saat ini, peneliti menggunakan enam dimensi kualitas SMART ASN Menuju 4.0 yaitu Rekrutmen Calon Pegawai Negeri Sipil (CPNS) menggunakan Computer Assisted Test (CAT), Pengembangan pola karier, Pengembangan kompetensi, Pengembangan karier, Promosi melalui seleksi terbuka, dan Rencana Suksesi dalam menciptakan SMART ASN Menuju 4.0 di kantor Kecamatan Sitinjau Laut. Tugas pemerintahan dilaksanakan dalam rangka penyelenggaraan fungsi umum
\end{abstract}


pemerintahan yang meliputi pendayagunaan kelembagaan, kepegawaian, dan ketatalaksanaan. Sedangkan tugas pembangunan tertentu dilaksanakan melalui pembangunan ekonomi dan sosial yang diarahkan meningatkan kesejahteraan dan kemakmuran seluruh masyarakat.

Kata Kunci : SMART, ASN Menuju 4.0

\section{PENDAHULAN}

Untuk kelancaran roda pemerintahan administrasi, Camat harus selalu mengadakan koordinasi dengan pemerintah tingkat dibawahnya dalam hal ini adalah seluruh staf dilingkungan wilayah kecamatan dan seluruh staf di lingkungan Kelurahan atau desa masing - masing serta melakukan koordinasi dengan para aparat atau pejabat di tingkat atasannya. Aparat yang setingkat dalam tingkat organisasi, dengan adanya koordinasi yang baik diharapkan dapat mewujudkan suatu tujuan yang kompak, penyatuan dan penyelarasan kegiatan - kegiatan pemerintahan sehingga tidak berjalan sendiri - sendiri. Camat senantiasa harus dapat melakukan koordinasi sehingga tidak terjadi kesenjangan disegala bidang. Guna memenuhi tuntutan pelayanan umum yang prima sebagaimana dipersyaratkan diatas, maka aparat ditingkat kecamatan dan kelurahan dituntut untuk profesional, memiliki sistim dan prosedur pelayanan yang transparan dan terpadu, partisipasi masyarakat yang respontif dan adaptif terhadap setiap perubahan yang terjadi. Kualitas dari Kantor Camat Kecamatan sangat menentukan baik buruknya pelayanan yang diberikan kepada masyarakat. Untuk itu, perlu dilakukan usaha-usaha untuk meningkatkan kualitas pelayanan terhadap masyarakat, yaitu melalui pembinaan terhadap Aparat Kecamatan dengan cara memberikan kesempatan dan tangung jawab kepada aparat kecamatan guna meningkatkan cara kerja, kesempatan dan keterampilan yang mendukung pelaksanaan pekerjaan dan mampu memberikan kontribusi yang cukup terhadap jalannya roda pemerintahan kecamatan.

Pelayanan yang baik kepada masyarakat harus didukung oleh pegawaipegawai yang handal, berkompeten, mampu memahami serta dapat melaksanakan tugas pokok dan fungsinya sesuai dengan bidang tanggung jawab yang dibebankan kepadanya. Selain itu, mereka tentu harus memiliki komitmen dan tanggung jawab moral terhadap masyarakat. Masyarakat tentunya ingin mendapatkan kualitas pelayanan yang baik dari pemerintah. Pelayanan yang berkualitas atau yang biasa disebut dengan pelayanan prima merupakan pelayanan terbaik yang memenuhi standar kualitas pelayanan.

Berdasarkan observasi yang dilakukan penulis pada pertengahan bulan Juni di Kantor Camat Kecamatan Sitinjau Laut, Penulis menemukan masalah terkait pelayanan publik. Masalah terkait pelayanan publik tersebut yaitu

1. Pegawai Kantor Camat Kecamatan Sitinjau Laut secara umum sudah dilaksanakan dengan mengacu pada prinsip-prinsip SMART 4.0. Prinsipprinsip tersebut diterapkan dalam penyelenggaraan pelayanan administrasi terpadu kecamatan ditujukan agar pelayanan yang diselenggarakan dapat lebih memberi kemudahan kepada masyarakat. Prinsip-prinsip tersebut 
meliputi prinsip akuntabilitas, keterbukaan atau transparasi, kepastian hukum dan profesionalisme.

2. Pegawai Kantor Camat Kecamatan Sitinjau Laut belum maksimal dalam menerapkan prinsip-prinsip SMART 4.0. Prinsip-prinsip tersebut dibuktikan dengan dua pegawai dari bagian pemerintahan yang bertugas di tempat loket pelayanan tersebut sehingga petugas harus membagi tugasnya. Ketiadaan petugas ini menyebabkan pengguna layanan harus menunggu dan bahkan pelayanannya dilakukan oleh pegawai yang lain. Selanjutnya mengenai ketiadaan petugas di meja buku tamu. Peneliti sudah beberapa kali datang ke Kecamatan Sitinjau Laut, di sana tersedia meja untuk menulis buku tamu namun penulis tidak menemukan petugas yang menjaga meja tersebut. Sedangkan selain menjaga buku tamu, petugas mempunyai tugas untuk memberi tahu alur atau proses keperluan pengguna layanan.

3. Mengenai keramahan pegawai di Kecamatan kepada pengguna layanan yang datang. Ketidakramahan tersebut terlihat ketika pegawai yang tidak memberikan senyum kepada pengguna layanan, petugas yang mengobrol dengan petugas lain yang membicarakan permasalahan yang tidak berkaitan dengan pelayanan yang diberikan sehingga masyarakat yang sedang menerima layanan tidak dilayani dengan baik. Selain itu penulis menemukan adanya respon pegawai yang tidak tanggap dengan masyarakat yang ingin melakukan pelayanan dan belum mengerti mengenai prosedur pelayanan. Sikap tidak tanggap sangat menganggu kualitas pelayanan yang di rasakan oleh masyarakat yang datang dan ingin mendapatkan pelayanan yang baik.

4. Mengenai sarana yang masih kurang dalam penerapan prinsip-prinsip SMART 4.0, misalnya filing cabinet yang berfungsi untuk menyimpan berkas dan memudahkan pegawai dalam mencari berkas namun didapati berkas yang disimpan dalam filing cabinet penataannya kurang rapi dan tidak ditemukan aturan dalam penyimpanan, sehingga ketika pegawai membutuhkan berkas/data tersebut pegawai mengalami kesulitan dalam menemukan berkas yang akan dibutuhkan. Sarana dan prasarana yang baik dibutuhkan agar masyarakat merasa lebih puas dengan pelayanan yang diberikan.

Pada kenyataannya dalam penerapan prinsip-prinsip SMART 4.0 sering kali pegawai dalam pelayanan tidak melakukan pekerjaannya dengan baik. Salah satunya adalah pelayanan terhadap masyarakat yang dilakukan tidak seperti yang diharapkan. Padahal, pelayanan yang diharapkan oleh masyarakat adalah pelayanan yang tercantum pada sendi - sendi pelayanan yang baik menggunakan prinsipprinsip SMART 4.0, seperti yang telah dicantumkan diatas. Sebagai pelayan masyarakat, Aparat Kecamatan harus memahami pelayanan seperti apa yang diinginkan oleh masyarakat. Akan tetapi, pada kenyataannya bertolak belakang dengan yang diharapkan. Masyarakat sering kali merasakan ketidakpuasan terhadap pelayanan yang diberikan oleh aparat kecamatan, karena pelayanan yang diberikan seringkali membuat masyarakat kecewa.

Untuk itu aparat pemerintah tentunya lebih meningkatkan keterampilan atau keahlian dan semangat yang tinggi sebagai penyedia 
layanan publik, sehingga pelayanan dapat diterima secara maksimal dan memberikan kepuasan bagi masyarakat. Mengingat Kecamatan adalah ujung tombak yang langsung berhubungan dengan masalah-masalah masyarakat, maka buruknya profesionalisme pegawai seperti yang diuraikan di atas akan mempengaruhi citra pelayanan publik di mata masyarakat. Artinya jika pelayanan di tingkat Kecamatan baik, maka secara umum tanggapan masyarakat terhadap pelayanan publik juga baik, begitu pula sebaliknya. Untuk bisa mewujudkan pelayanan yang baik tersebut maka di butuhkan aparat yang profesional dalam menjalankan tugasnya.

\section{METODE PENELITIAN}

\section{Pendekatan Penelitian Yang Digunakan}

Dalam Penelitian ini penulis menggunakan pendekatan kualitatif yaitu meneliti suatu objek penelitian dengan mengkaji secara keseluruhan dan mendalam.

\section{Informan Penelitian}

Yang menjadi informan dalam penelitian ini adalah pegawai dan nasabah yang ada di Kantor Sitinjau Laut Kabupaten Kerinci sebanyak 8 orang pegawai

\section{Data Yang Akan Diambil}

1. Data primer diperoleh dalam bentuk verbal atau kata-kata atau ucapan lisan dan perilaku dari subjek (informan) yang berkaitan dengan objek penelitian, terhadap Menciptakan SMART ASN Menuju 4.0 di Kantor Camat Kecamatan Sitinjau Laut Kabupaten Kerinci.

2. Data sekunder yaitu berupa tulisan-tulisan, rekaman-rekaman, gambar-gambar atau foto-foto, peta, grafik yang semuanya berhubungan dengan objek penelitian. Data sekunder dalam penelitian ini adalah Peraturan-peraturan mengenai pelaksanaan Menciptakan SMART ASN Menuju 4.0 di Kantor Camat Kecamatan Sitinjau Laut Kabupaten Kerinci atau program-program yang telah dijalankan berhubungan dengan pelaksanaan Kantor Camat Kecamatan Sitinjau Laut KABUPATEN KERINCI.

\section{Teknik Pengumpulan Data Yang Digunakan}

1. Penelitaian Perpustakaan (Library Research)

2. Penelitian Lapangan (Field Research)
Alat Pengumpulan Data
1. Pedoman Wawancara
2. Pensil dan Pena
3. Kertas
4. Laptop
5. Smartphone

Adapun alat yang di gunakan dalam penelitian ini : 


\section{Analisis Data}

Menurut Miles dalam Emzir (2010 : 129) analisa data ada tiga cara yaitu:

\section{Reduksi data}

Reduksi data merupakan suatu bentuk analisis yang mempertajam,memilih, memfokuskan, membuang, dan menyusun data dalam suatu cara dimana kesimpulan akhir dapat diverifikasi. Data kualitatif dapat direduksi dan ditransformasikan dalam banyak cara yaitu melalui seleksi harus melalui rangkuman atau parafrase.

\section{Penarikan/Verifikasi kesimpulan}

Langkah ketiga dari aktivitas analisis merupakan penarikan yang berisikan kesimpulan. Kesimpulan akhir tergantung pada kumpulan dari catatan lapangan, penyimpangan, dan metode-metode perbaikan yang digunakan tuntutan dari penyandang dan tetapi kesimpulan bahkan ketika seorang menyatakan telah memproses secara induktif.

\section{HASIL DAN PEMBAHASAN}

\section{Rekrutmen Calon Pegawai Negeri Sipil (CPNS) menggunakan Computer Assisted Test (CAT)}

Computer Assisted Test didefinisikan sebagai suatu metode ujian dengan menggunakan alat bantu komputer yang digunakan untuk mendapatkan standar minimal kompetensi dasar maupun standar kompetensi kepegawaian (BKN, 2014). Adapun tahapan proses dalam perancangan sistem CAT diawali dengan penelitian dan pengumpulan data, kemudian perencanaan, pembuatan prototipe, pelaksanaan uji coba, dan diikuti perbaikan dan pengembangan. Protipe sistem CAT mempunyai karakteristik sebagai berikut: (1) Aplikasi menggunakan platform windows atau open source yang berbasis website; (2) Adanya narasi yang berisi petunjuk yang disajikan pada layar monitor komputer; (3) Aplikasi disertai video gerakan mouse untuk memudahkan pengguna dalam mengoperasikannya, dan (4) Dilengkap tutorial dan teks yang berisi petunjuk pada layar monitor komputer agar semua peserta tes mudah dalam mengoperasikannya.

Prinsip-prinsip Dasar Sistem CAT Menurut BKN (2014), CAT sebagai salah satu metode yang digunakan dalam pelaksanaan tes mempunyai prinsip dasar sebagai berikut; (1) Sistem CAT dirancang semudah mungkin, sehingga peserta tes dapat mengoperasikannnya; (2) Cara mengoperasikan sangat mudah, bahkan bagi pemula sekalipun karena hanya dengan menggunakan mouse untuk mengerjakan soal tes dan memilih jawaban. Panitia wajib memberikan pengarahan dan menayangkan video petunjuk cara pengoperasian sistem CAT untuk memberi petunjuk penggunaan sistem CAT; (3) Soal yang ada dalam aplikasi CAT bervariasi namun dengan tingkat kesulitan yang setara. Peserta mendapatkan soal berbeda, dan soal diacak secara otomatis kemudian didistribusikan ke masing-masing komputer peserta; dan (4) Pemeriksaan hasil tes langsung dilakukan oleh aplikasi secara otomatis. Nilai peserta dapat dipantau secara bersamaan melalui ruang monitoring di luar tempat pelaksanaan tes. Smentara peserta tes dapat mengetahui nilai yang diperoleh 
sesaat setelah menyelesaikan ujian melalui layar monitor masing-masing computer

Dasar hukum pelaksanaan rekrutmen CPNS menggunakan sistem CAT yaitu surat Menteri Pendayagunaan Aparatur Negara dan Reformasi Birokrasi Nomor: B- 2432/M.PAN.RB/7/2013 tanggal 12 Agustus 2013 tentang penerapan Sistem CAT dalam seleksi CPNS dengan ketentuan sebagai berikut:

\section{Metode Rekrutmen}

Metode yang digunakan dalam rekrutmen CPNS menggunakan sistem CAT yaitu metode rekrutmen dari luar (rekrutmen eksternal) yang meliputi:

1. Institusi Pendidikan

Rekruitmen karyawan dapat berasal dari kalangan lembaga pendidikan. Hal ini diterapkan pada lulusan sekolah kedinasan yang ingin menjadi PNS misalnya CPNS Kementrian Keuangan diambil dari sekolah kedinasan STAN. Seperti yang diutarakan bapak DH (45) "Sebenarnya CAT ini bukan sekedar CPNS, tapi juga sekolah tinggi kenegaraan”.

2. Iklan

Sesuai Peraturan Kepala Badan Kepegawaian Negara Nomor 9 Tahun 2019 Tentang Pedoman Pelaksanaan Pengadaan CPNS dari Pelamar Umum mengenai ketentuan pengumuman penerimaan bahwa "pengumuman harus menggunakan media yang mudah diketahui masyarakat luas, antara lain melalui media elektronik (televisi, radio, internet), media cetak, papan pengumuman dan/atau bentuk lain yang memungkinkan".

Pelaksanaan rekrutmen CPNS menggunakan sistem CAT memerlukan sarana dan prasarana antara lain

1) Ruang registrasi peserta: digunakan untuk registrasi peserta tes CPNS yang dilakukan oleh panitia dari instans

2) Ruang verifikasi peserta: digunakan untuk melakukan verifikasi/ memastikan kebenaran identitas dari peserta yang akan melakukan TKD, yang dilakukan oleh panitia dari instansi

3) Area penitipan barang: area yang digunakan untuk menitipkan barangbarang bawaan peserta seperti tas, handphone, dan lainnya. Peserta TKD CAT tidak diperkenankan membawa barang apapun selain kartu ujian dan Id Card.

4) Ruang tunggu CAT: ruangan yang disediakan untuk peserta TKD CAT sebelum memasuki ruangan CAT. Selain itu peserta diberi kesempatan untuk mempersiapkan diri sebelum mengikuti ujian TKD CAT.

Ruang Monitoring: digunakan untuk memonitor pelaksanaan TKD, pada ruangan tersedia layar monitor untuk melihat hasil ujian peserta TKD CAT. Selain itu,ruangan ini juga sebagai tempat memantau pelaksanaan tes per sesi dan untuk penandatanganan hasil tes per sesi.

Ruang server: ruangan untuk menempatkan server dan pirantipiranti jaringan lokal. Ruangan server harus ditempatkan secara khusus karena untuk keamanan data dan hanya petugas tertentu yang 
diperbolehkan masuk ruangan tersebut. Ruangan server harus tersedia Uninterruptible Power Supply (UPS) untuk mengamankan server dari permasalahan listrik/ pemadaman listrik.

\section{Prosedur Rekruitmen}

Calon pelamar perlu mengikuti serangkaian prosedur rekrutmen yang telah ditetapkan oleh suatu organisasi sebagai salah satu langkah untuk menjadi pegawai. Badan Kepegawaian Nasional telah menyusun prosedur rekrutmen CPNS yang meliputi:

b. Pelamar melakukan registrasi online ke portal BKN dan cetak bukti pendaftaran peserta untuk digunakan dalam proses validasi dokumen di instansi

c. Pelamar mengirimkan berkas lamaran yang diperlukan ke instansi yang dilamar dengan disertai nomor pendaftaran peserta

d. Petugas pendaftaran di instansi melakukan verifikasi kelengkapan dan kebenaran dokumen lamaran, sesuai dengan data peserta yang sudah di entry di portal.

e. Pelamar meminta Nomor Peserta Tes Ujian CPNS kepada panitia seleksi instansi apabila berkas lamaran dinyatakan lengkap dan benar.

f. Pelamar mengikuti ujian TKD (sistem LJK atau CAT sesuai yang digunakan oleh instansi) pada waktu dan tempat yang ditentukan oleh panitia seleksi instansi.

g. Pelamar dapat melihat perolehan nilai TKD melalui web atau media yang tersedia. Bagi peserta yang dinyatakan lulus ujian TKD, berhak mengikuti tes TKB apabila dilaksanakan oleh instansi yang dilamar.

Prosedur rekrutmen CPNS sistem CAT diuraikan sebagai berikut:

a. Pelamar mengajukan surat lamaran, yang disertai dengan lampiran persyaratan yang dibutuhkan.

Pelaksanaanya dilakukan dengan melakukan registrasi online ke portal BKN (http://sscn.bkn.go.id). Pelamar kemudian mencetak bukti pendaftaran peserta untuk digunakan dalam proses validasi dokumen di instansi. Setelah itu berkas lamaran yang diperlukan dikirim ke instansi yang dilamar dengan disertai nomor pendaftaran peserta. Persyaratan tergantung dari masing-masing instansi yang membuka rekrutmen pegawai.

b. Setelah lamaran diajukan maka diberikan tanda bahwa lamarannya sudah terdaftar oleh petugas yang berwenang pada instansi tersebut.

Petugas pendaftaran di instansi melakukan verifikasi kelengkapan dan kebenaran dokumen lamaran, sesuai dengan data peserta yang sudah di entry di portal. Pelamar meminta Nomor Peserta Tes Ujian CPNS kepada panitia seleksi instansi apabila berkas lamaran dinyatakan lengkap dan benar.

1) Pada saatnya, pelamar yang bersangkutan mendapat panggilan untuk mengikuti ujian yang diadakan, kapan ujian akan diselenggarakan, 
dan mata ujian apa saja yang akan diujikan. Kewenangan untuk menentukan waktu pelaksanaan ujian berada ditangan BKN pusat. Ujian berupa Tes, Kompetensi Dasar (TKD) yang terdiri dari tiga jenis soal yaitu:

2) Pada saat ujian diadakan, adapun metodenya berupa :

a) Check points. Tes Kompetensi Dasar menggunakan metode CAT merupakan bentuk tes pengerjaan soal dengan memilih satu yang dianggap paling tepat dari beberapa pilihan jawaban yang tersedia. Tes Kompetensi Bidang harus dilaksanakan oleh seluruh pelamar yang berasal dari masyarakat umum.

b) Metode wawancara. Metode wawancara dapat digunakan sebagai bentuk Tes Kompetensi Bidang (TKB). Pelaksanaan wawancara tergantung dari keputusan instansi yang bersangkutan, apakah akan mengadakan atau tidak.

c) Penerimaan calon pegawai diberikan kepada mereka yang lulus tahap akhir dengan mengadakan peringkat yang jumlahnya dibatasi pada jumlah calon pegawai yang dibutuhkan.

\section{Pengembangan karier}

Dalam rangka mencapai tujuan nasional sebagaimana tercantum dalam Pembukaan UUD 1945, Aparatur Sipil Negara atau Pegawai Negeri Sipil sebagai unsur utama sumberdaya manusia aparatur negara/pemerintah mempunyai peranan yang sangat strategis dalam mengemban tugas pelayanan publik, tugaspemerintahan, dan tugas pembangunan tertentu. Tugas pelayanan publik dilakukan dengan memberikan pelayanan atas barang, jasa, dan atau pelayanan administratif.

Tugas pemerintahan dilaksanakan dalam rangka penyelenggaraan fungsi umum pemerintahan yang meliputi pendayagunaan kelembagaan, kepegawaian, dan ketatalaksanaan. Sedangkan tugas pembangunan tertentu dilaksanakan melalui pembangunan ekonomiaa dan social yang diarahkan meningatkan kesejahteraan dan kemakmuran seluruh masyarakat (Penjelasan Umum UU.No.5 Tahun 2014)

Untuk dapat menjalankan tugas pelayanan publik, tugas pemerintahan, dan tugas pembangunan tersebut, ASN/PNS harus memiliki profesi dan manajemen ASN/PNS yang berdasarkan pada Sistem Merit atau perbandingan antara kualifikasi, kompetensi, dan kinerja yang dibutuhkan oleh jabatan dengan kualifikasi, kompetensi dan kinerja yang dimiliki oleh calon dalam rekrutmen, pengangkatan, penempatan, dan promosi pada jabatan yang dilaksanakan secara terbuka dan kompetitif, sejalan dengan tata kelola pemerintahan yang baik. Untuk itu dilakukan manajemen ASN/PNS yang meliputi penyusunan dan penetapan kebutuhan, pengadaan, pangkat, dan jabatan, pengembangan karier, pola karier, promosi, mutasi, penilaian kinerja, penggajian dan tunjangan, penghargaan, disiplin.

Pengguna layanan akan merasa senang ketika pegawai layanan melakukan proses pelayanan dengan cepat dan tepat. Tepat dapat diartikan pegawai memberikan layanan sesuai dengan keperluan pengguna layanan. Pelayanan yang 
tepat merupakan kesesuaian antara pelayanan yang diberikan dengan keperluan pengguna layanan sehingga keperluan yang dihadapi pengguna layanan dapat terselesaikan dengan baik dan pada akhirnya kepuasan Masyarakat tercapai. Contohnya saat pengguna layanan yang akan melegalisir KK, ketika pegawai memanggil pengguna layanan sesuai antriannya, kemudian pegawai langsung memberikan pelayanan dengan cepat, sehingga pengguna puas dengan pelayanan yang diberikan. Namun tidak semua pegawai dapat melayani dengan cepat. Semua itu tergantung ada atau tidaknya pegawai yang ada di ruang pelayanan. Jika pegawai hanya ada satu atau dua sedangkan yang mengantri ada banyak maka kemungkinan untuk melayani dengan cepat akan sedikit

Pelayanan yang cepat dan tepat merupakan hal penting yang harus dilakukan sebagai bentuk Pengembangan karir terhadap pengguna layanan, akan tetapi selain cepat pelayanan juga harus dilakukan dengan tepat. Jika pegawai sudah memberikan pelayanan dengan cepat dan teliti maka pegawai layanan sudah menjalankan tugas dengan profesional sehingga pengguna layanan akan merasa senang

\section{Pengembangan Kompetensi}

Pengembangan kompetensi merupakan kemampuan unit pelayanan dalam memberikan pelayanan yang dijanjikan dengan segera dan memuaskan. Pengembangan kompetensi ini juga merupakan kemampuan penyedia layanan untuk memberikan pelayanan secara tepat waktu dan konsisten. Kehandalan dapat diartikan mengerjakan dengan benar sesuai dengan prosedur kerja, standar pelayanan dan waktu yang telah dijanjikan. Pemenuhan pelayanan yang tepat dan memuaskan meliputi ketepatan waktu, kecakapan dalam memberikan layanan serta kecakapan dalam menanggapi keluhan jika ada keluhan yang Bapakuk dari pelanggan serta pemberian pelayanan secara wajar dan akurat. Untuk mengukur Pengembangan kompetensi dalam upaya mengetahui kualitas SMART ASN Menuju 4.0 di Kantor Kecamatan Sitinjau Laut dapat diukur melalui indikator sebagai berikut

a. Kecermatan pegawai dalam melayani pengguna layanan Kecermatan atau ketelitian pegawai dalam melayani pengguna layanan sangat penting bagi proses pelayanan. Jika pegawai tidak cermat dalam melayani Masyarakat maka akan terjadi kesalahan dan menimbulkan pekerjaan baru. Sebagai contoh ketika pegawai salah ketik dalam penulisan nama pada KTP, maka pengguna layanan harus keibukli nama yang salah tersebut. Dari ketidakcermatan tersebut akan menimbulkan pekerjaan baru yang seharusnya tidak perlu dilakukan oleh pegawai, serta akanmenimbulkan penilaian yang kurang baik oleh pengguna layanan terhadap kualitas pelayanan yang diberikan. Maka dari itu pegawai harus cermat dalam mengerjakan tanggung jawab tugas khususnya yang berkaitan dengan pelayanan agar tercipta pelayanan yang baik dan Masyarakat akan menilai baik. Berdasarkan penelitian yang dilakukan, pegawai kantor Kecamatan Sitinjau Laut sudah cermat atau teliti dalam melayani Masyarakat.

b. Memiliki Standar Pelayanan yang jelas

Memiliki Standar SMART ASN Menuju 4.0 yang jelas memang penting 
untuk pedoman pegawai dalam melayani pengguna layanan dalam proses pelayanan karena dengan berpatokan kepada Standar Pelayanan, proses pelayanan dapat berjalan dengan baik guna mencapai tujuan pelayanan khususnya di Kecamatan Sitinjau Laut.

c. Kemampuan Pegawai dalam menggunakan alat bantu dalam proses pelayanan

Kemampuan pegawai menggunakan alat bantu dalam proses pelayanan merupakan modal yang sangat penting dalam menunjang kualitas pelayanan. Namun, berdasarkan penelitian yang dilakukan, pegawai pelayanan yang ada di Kecamatan Sitinjau Laut belum semuanya mampu untuk menggunakan alat bantu yang ada di ruang pelayanan. Hanya ada satu atau dua orang yang mampu mengoperasikan kamera untuk keperluan foto KTP, komputer dan perangkatnya sebagai alat bantu pelayanan. Seharusnya sudah semua mampu menguasai alat bantu dalam proses pelayanan.

\section{Pengembangan pola karier}

Dalam hubungan dengan pengembangan karier ASN, UU.No.5 Tahun 2014 (pasal 69) menegaskan : (1) pengembangan karier ASN dilakukan berdasarkan kualifikasi, kompetensi, penilaian kinerja, dan kebutuhan instansi pemerintah; (2) pengembangan karier ASN/PNS dilakukan dengan mempertimbangkan integritas dan moralitas; (3) kompetensi meliputi : kompetensi teknis yang diukur dari tingkat dan spesifikasi pendidikan, pelatihan teknis fungsional, dan pengalaman bekerja; kompetesi manajerial yang diukur dari tingkat pendidikan, pelatihan struktural atau manajemen, dan pengalaman kepemimpinan; dan kompetensi sosial kultural yang diukur dari pengalaman kerja berkaitan dengan masyarakat majemuk dalam hal agama, suku, dan budaya sehingga memiliki wawasan kebangsaan. (4) Integritas diukur dari kejujuran, kepatuhan terhadap ketentuan perundang-undangan, kemampuan bekerjasama, dan pengabdian kepada masyarakat, bangsa dan Negara. (5) Moralitas diukur dari penerapan dan pengalaman nilai etika agama, budaya, dan sosial

Di satu pihak, ada pegawai yang dilihat dari segi kualifikasi, kompetensi dan kinerja kurang memenuhi syarat, namun mendapat kesempatan lebih banyak dalam pengembangan karier (seperti kesempatan mengikuti pendidikan dan Pelatihan jabatan, mengikuti kursus/penataran dan pelatihan teknis tertentu, ditempatkan pada posisi yang lebih baik atau lebih besar tanggung jawabnya, dan kesempatan promosi); di lain pihak, ada pegawai yang lebih baik atau lebih memenuhi persyaratan namun kurang diperhatikan dan kurang diberi kesempatan untuk pengembangan karier.Akibatnya, ada pegawai yang perkembangan kariernya lebih baik dan berjalan cepat, dan ada pula pegawai yang perkembangan kareirnya berjalan lambat dan bahkan ada yang mentok sementara atau tidak jalan.

\section{Promosi melalui seleksi terbuka}

Inovasi dalam sektor publik menjadi sebuah keniscayaan seiring dengan semangat perjuangan dalam melakukan reformasi birokrasi. Konsep inovasi dalam kajian administrasi publik tertuang dalam perspektif New Public Management dan Reinventing Government (Taufik, \& Astuti, 2019). Konsep ini menjelaskan bagaimana kemampuan organisasi untuk survive dan meningkatkan kinerja dengan 
mengadopsi semangat yang dijalankan dalam sektor swasta ke sektor publik (Osborne \& Gaebler 1992). Mengadopsi semangat kerja di sektor swasta telah banyak melahirkan berbagai inovasi-inovasi yang dapat dikembangkan di sektor publik.

Pandangan lain mengenai pengertian inovasi dikemukakan oleh (Lynn, 1997) yang menjelaskan bahwa inovasi (dalam organisasi pemerintah) merupakan transformasi dari fungsi utama organisasi dan perubahan yang permanen dan mendasar dalam struktur organisasi .Berkenaan dengan hal itu, (Rogers, 2003) juga berpendapat bahwa "an innovation is an idea, practice, or object that is perceived as new by individual or other unit of adopter". Pandangan dari Rogers melihat sebuah inovasi dapat dimaknai sebagai sebuah ide, praktek, atau objek yang dianggap baru oleh individu atau satu unit adopsi lainnya. Pengertian inovasi dari Rogers ini menunjukkan bahwa inovasi dapat berupa sebuah temuan baru atau juga berupa adopsi dari inovasi lainnya. Dari pengertian inovasi di atas dapat disimpulkan bahwa inovasi dapat berupa sebuah ide, gagasan, cara, atau metode yang lama dengan yang baru yang fleksibel, dan mempunyai sifat membangun ke arah yang lebih baik. Inovasi dapat berupa dilihat dari sisi manajemen maupun kebijakan publik.

\section{Rencana Suksesi}

Dalam perencanaan suksesi yang mendukung pengembangan karir Pegawai Negeri Sipil (PNS) pada tingkat nasional. TM bertujuan agar organisasi memperoleh kandidat-kandidat pengisi jabatanjabatan strategisnya dari para pegawainya sendiri. Artinya TM ditujukan agar pengisi posisi-posisi kunci atau jabatan strategis dalam organisasi dapat diperoleh secara internal, yang mana diharapkan akan cenderung lebih memahami kondisi dan lingkungan serta kebutuhan riil dari organisasi yang bersangkutan. Selain itu, usaha untuk memperoleh kandidat secara internal juga akan membutuhkan lebih sedikit waktu dan biaya.

Agar TM memberikan hasil yang akurat dibutuhkan pengujian kompetensi dan penilaian kinerja yang baik. Penilaian kinerja harus benarbenar dilakukan secara objektif, menggunakan metode yang berorientasi pada hasil dan dampak, bukan hanya proses, serta terukur dan memberikan umpan balik yang nyata. Penilaian kinerja yang ada saat ini yaitu melalui penghitungan Sasaran Kinerja Pegawai (SKP) masih cenderung rendah objektivitasnya karena sangat dipengaruhi oleh kedekatan atau rasa kasihan, kurang jelas pengukurannya, dan kurang menggambarkan hasil kerja yang nyata. Perlu diterapkan metode penilaian dan ukuran kinerja lain yang lebih objektif dan terukur seperti misalnya metode penilaian kinerja 3600 dan mengubah formula penghitungan capaian kerja yang lebih jelas ukurannya, yaitu dengan lebih menekankan pada hasil kerja, bukan hanya pelaksanaan kegiatannya saja.

Rencana suksesi yaitu mencakup pengetahuan, kemampuan, kesopanan dan sifat dapat dipercaya yang dimiliki pegawai, bebas dari bahaya, resiko, dan keraguraguan. Jaminan adalah upaya perlindungan yang disajikan untuk Masyarakat bagi warganya tehadap resiko yang apabila resiko itu terjadi akan dapat mengakibatkan gangguan dalam struktur kehidupan yang normal. 
Untuk mengukur Rencana suksesi dalam upaya mengetahui kualitas SMART ASN Menuju 4.0 di Kantor Kecamatan Sitinjau Laut dapat diukur melalui indikator sebagai berikut :

a. Petugas memberikan jaminan tepat waktu dalam pelayanan

Pegawai di Kantor Kecamatan Sitinjau Laut memberika jaminan tepat waktu dalam pelayanan saat itu juga apabila bisa diselesaikan pegawai mengusahakan tepat waktu. Jika memang tidak bisa diselesaikan hari itu juga seperti contoh membuat KTP yang tidak bisa langsung selesai hari itu pegawai memberikan jaminan waktu dan memberikan bukti pengambilan agar ketika sudah selesai jangka waktunya langsung bisa diambil dengan menggunakan bukti pengambilan yang sudah diberikan kepada pelanggan tersebut.

Pegawai memang harus memberikan jaminan tepat waktu kepada pengguna layanan agar pengguna layanan tidak menunggu terlalu lama.

b. Petugas memberikan jaminan biaya dalam pelayanan

Dalam mengurus keperluan di Kecamatan, tidak semua mengeluarkan biaya untuk mengurusnya. Tergantung jenis pelayanannya. KTP, KK, dan surat-surat lainnya itu gratis kecuali IMB dan Ijin gangguan. Ketika mengamati, peneliti memang tidak melihat pengguna layanan memberikan uang kepada pegawai layanan kecuali pengguna layanan mengurus IMB dan ijin gangguan.

Pengguna layanan dalam proses pelayanan merupakan prioritas dalam pelayanan. Apapun keperluan pengguna layanan terkait pelayanan di Kecamatan harus pendapat prioritas utama dan harus sesuai dengan apa yang diperlukan oleh pengguna layanan. Namun ketika peneliti mengamati tidak semua pegawai mendahulukan kepentingan pengguna layanan. Terlihat ketika Bapakih ada pengguna layanan yang mengantri namun ada pegawai yang memiih untuk mementingkan urusan pribadinya seperti menjemput anak ke sekolah.

Mendahulukan kepentingan pengguna layanan memang penting karena pengguna layanan merupakan prioritas pegawai layanan. Jika pengguna layanan tidak merasa didahulukan akan timbul keluhan dan akan memberikan citra yang buruk bagi bagian pelayanan.

c. Petugas melayani dengan ramah dan sopan santun

Keramahan pegawai pelayanan sangat diperlukan dalam proses pelayanan. Jika pegawai pelayanan ramah maka akan memberikan penilaian yang baik dari pengguna layanan, karena pada dasarnya semua orang akan menyukai tempat pelayanan yang didalamnya banyak terdapat orang yang ramah. Orang yang ramah berati orang yang tanggap dengan keperluan orang lain. Selain ramah, sikap sopan santun juga sangat diperlukan oleh pegawai layanan untuk melayani pengguna layanan.

Keramahan dan sikap sopan santun pegawai pelayanan sangat diperlukan dalam proses pelayanan. Jika pegawai pelayanan ramah dan sopan santun maka akan memberikan penilaian yang baik dari pengguna layanan, karena pada dasarnya semua orang akan menyukai tempat pelayanan yang didalamnya banyak terdapat orang yang ramah dan sopan santun. Orang yang ramah berati orang yang tanggap dengan keperluan orang lain. Namun ketika peneliti mengamati, belum semua pegawai memberikan keramahan kepada pengguna layanan karena ada beberapa pegawai yang mengobrol dengan pegawai lain ketika melayani pengguna layanan. 
Sikap menghargai dalam melayani juga hampir sama dengan sikap sopan santun. Sikap menghargai dapat dilakukan dengan menyapa serta tersenyum dengan pengguna layanan, menanyakan dan mencatat keperluan pelanggan, memberikan penjelasan yang berkaitan dengan keperluan pelanggan, dan berusaha agar kebutuhan pelanggan dapat terpenuhi. Peneliti juga mengamati bahwa pegawai pelayanan Kecamatan Sitinjau Laut sudah semua memiliki sikap menghargai kepada pengguna layanan.

Pada setiap pelayanan tentunya harus ada hal-hal yang dapat membuat kenyamanan bekerja agar mendapat hasil yang maksimal. Faktor pertama yang digunakan untuk mendorong terciptanya pelayanan yang baik di Kecamatan Sitinjau Laut yaitu semangat yang diberikan pegawai satu sama lain,

\section{SIMPULAN}

Berdasarkan pada hasil penelitian dan pembahasan pada bab IV, maka peneliti dapat menarik beberapa kesimpulan bahwa untuk mengetahui kualitas SMART ASN Menuju 4.0 di Kantor Kecamatan Sitinjau Laut saat ini, peneliti menggunakan enam dimensi kualitas SMART ASN Menuju 4.0 yaitu Rekrutmen Calon Pegawai Negeri Sipil (CPNS) menggunakan Computer Assisted Test (CAT), Pengembangan pola karier, Pengembangan kompetensi, Pengembangan karier, Promosi melalui seleksi terbuka, dan Rencana Suksesi dalam menciptakan SMART ASN Menuju 4.0 di kantor Kecamatan Sitinjau Laut. Tugas pemerintahan dilaksanakan dalam rangka penyelenggaraan fungsi umum pemerintahan yang meliputi pendayagunaan kelembagaan, kepegawaian, dan ketatalaksanaan. Sedangkan tugas pembangunan tertentu dilaksanakan melalui pembangunan ekonomi dan sosial yang diarahkan meningatkan kesejahteraan dan kemakmuran seluruh masyarakat (Penjelasan Umum UU.No.5 Tahun 2014)

\section{UCAPAN TERIMAKASIH}

Diucapkan terimakasih kepada semua pihak yang telah berkontribusi dalam penelitian ini, sehingga penelitian dapat terlaksana dengan baik.

\section{DAFTAR PUSTAKA}

Achmadi. 2007. Metodologi Penelitian. Jakarta: Bumi Aksara.

Dimock dan Dimock. 1992. Ilmu Administrasi Negara. Jakarta: Rineka Cipta

Faisal, Sanapiah. 1990. Penelitian Kualitatif (dasar-dasar dan aplikasi). Malang: Ya3 Malang.

Hasibuan. Malayu S.P. 2011. Manajemen Sumber Daya Manusia. Jakarta: PT Bumi Askara.

Huberman. 1992. Analisis Data Kualitatif Buku Sumber Tentang Metode-metode Baru.Jakarta: UIP.

Mangkunegara. 2011. Manajemen Sumber Daya Perusahaan. PT . Remaja. Rosdakarya. Bandung.

Moekijat. 2016. Perencanaan Sumber Daya Manusia. Bandung: Mandar Maju. 
R. 2002. Pertanian Organik: Menuju Pertanian Alternatif dan Berkelanjutan. Yogyakarta: Kanisius.

Nawawi. 2017. Perencanaan SDM Untuk Organisasi Profit Yang Kompetitif. Yogyakarta: UGM Press.

Nur Aini Harahap, Khairunnisa, Juanita Tanuwijaya, 2017, Tingkat Pengetahuan Pasien dan Rasionalitas Swamedikasi di Tiga Apotek Kota Penyambungan, Jurnal Sains dan Klinis. Ikatan Apoteker Indonesia. Sumatera Barat.

Pebi Julianto. 2020. Pengaruh Disiplin Kerja Terhadap Prestasi Kerja Pegawai pada Puskesmas di kecamatan Depati VII Kabupaten Kerinci. E Jurnal Administrasi Nusantara. Sungai Penuh.

Pebi Julianto. 2020. Partisipasi Masyarakat Dalam Program Bantuan Stimulan Perumahan Swadaya (BSPS) di Desa Koto Baru Kecamatan Koto baru (2020). E Jurnal Qawwam. Kerinci.

Rivai, 2004, "Manajemen Sumber Daya Manusia Untuk. Perusahaan,Cetakan Pertama, Jakarta, PT. Raja GrafindoPersada.

Robbins Stephen P et al. 1993. Organization Behavior. Australia: Prentice Hall.

Waldo. Dwight. 1996. Pengantar Studi Public Administration. Bumi Aksara. Jakarta.

Sedarmayanti. M.Pd.. APU. 2009. Sumber Daya Manusia dan Produktivitas. Kerja. Bandung : Penerbit Mandar Maju.

Sedarmayanti. (2002). Metodologi Penelitian. Bandung : Mandar Maju.

Siagian, Sondang. P. 2014. Manajemen Sumber Daya Manusia. Jakarta: Bumi Aksara.

Sutrisno. E. 2017. Manajemen Sumber Daya Manusia. Kencana. Jakarta.

Thoha. Miftah. 1997. Pembinaan Organisasi Proses Diagnosa dan Intervensi. Jakarta : PT. Raja Grafindo Persada 